\title{
An analysis of the consequences of acute appendicitis between urban and rural patients in Bangladesh
}

\author{
Tasnuva Iqbal $^{1}$ (D), Khondker Abul Kalam Azad ${ }^{2}$ (D), Muhammad Irfanul Alam³ (D), Mainul Haque M $^{*}$ (D) \\ ${ }^{1}$ Department of Surgery, Chattogram International Medical College and Hospital, Chattogram, Bangladesh. \\ ${ }^{2}$ Chattogram Medical College Hospital, Chattogram, Bangladesh. \\ ${ }^{3}$ École des hautes études en santé publique (EHESP French School of Public Health), Campus de Paris: Saint-Denis, Île-de-France. \\ ${ }^{4}$ Unit of Pharmacology, Faculty of Medicine and Defence Health, Universiti Pertahanan Nasional Malaysia National Defence University of Malaysia, Kuala \\ Lumpur, Malaysia.
}

\section{ARTICLE INFO \\ Received: 23/04/2021 \\ Accepted: 18/06/2021 \\ Available Online: 05/08/2021}

\begin{abstract}
In acute appendicitis, timely diagnosis and rapid intervention are critical for effective management. However, geographic location and socioeconomic context can play an important role in developing countries' clinical course and outcome. The aim of this study is to observe the consequences of acute appendicitis between urban and rural patients. A prospective analytical study was conducted from April 25 to October 25, 2016, in Chittagong Medical College Hospital, Chattogram, Bangladesh. A total of 200 patients, 100 patients in each arm with a clinical diagnosis of acute appendicitis, were enrolled. 33.5\% were in the age group of 21-30 years. The male:female ratio was 1.94:1. $45 \%$ of the urban patients came from the middle class, while $47 \%$ of the rural patients were from poor socioeconomic backgrounds. The mean duration of the presentation was $2.96 \pm 1.88$ days in urban and $5.28 \pm 2.8$ days in rural patients. $87 \%$ of urban and $33 \%$ of rural patients received conservative treatment before hospitalization. $74.11 \%$ of rural and $30 \%$ of urban patients delayed consenting to surgery. Perforation was found in $17.78 \%$ of urban and $33.33 \%$ of rural patients and gangrenous appendicitis in $12.22 \%$ of urban and $66.67 \%$ of rural patients. Rural patients suffered more complications like wound infection ( $34.4 \%$ and $68.4 \%$, resp.), septic shock ( $0 \%$ and $7.9 \%$, resp.), burst abdomen $(0 \%$ and $5.3 \%$, resp.), and death in two rural patients. Mean hospital stay was $4.37 \pm 1.69$ days in urban and $8.41 \pm 2.44$ days in rural patients. The rural population has higher morbidity and mortality when compared to the urban population of Bangladesh.
\end{abstract}

\section{INTRODUCTION}

Appendicitis is the most common abdominal surgical emergency (Sammalkorpi et al., 2014). Appendicitis is associated with high morbidity in developing countries (Kong et al., 2015). There is a higher incidence in developed cities due to fat-rich and fiber-low urban diets (Jones et al., 2021; Walker et al., 1973). However, there is not much research to identify precise data on geospatial variation, gender distribution, urban-rural discrepancy,

\section{${ }^{*}$ Corresponding Author}

Mainul Haque, Unit of Pharmacology, Faculty of Medicine and Defence Health, Universiti Pertahanan Nasional Malaysia (National Defence University of Malaysia), Kuala Lumpur, Malaysia.

E-mail: runurono@gmail.com or acute appendicitis in Bangladesh (Bashar et al., 2014; Islam et al., 2020a). Although it has been reported that the incidence of appendicitis is lower in developing countries than those in developed countries, the incidence of complications and fatal outcome is higher than in developed countries (Yang et al., 2015). Multiple studies revealed that nonperforated appendicitis incidence was highest among adolescents and adults (Boland et al., 2021; Humes \& Simpson, 2006; Körner et al., 1997). On the contrary, perforated appendicitis had a higher incidence rate in small children and the elderly, irrespective of gender. In addition, perforated appendicitis had a considerably longer duration of symptoms and hospital stay (Papandria et al., 2013; Williams et al., 2021).

Bangladesh is experiencing a dietary habit and lifestyle modification due to ongoing industrialization and 
rapid urbanization, which exhibits a pattern similar to countries going through the same phase, which is the major contributor to developing chronic diseases (Allender et al., 2008; Al-Shoaibi et al., 2018; Islam et al., 2020b). Simultaneously, in the rural population, inability to access healthcare, health-seeking behavior, poverty, illiteracy, and faith in traditional remedies are significant constraints for achieving good healthcare services (Kabir et al., 2019; Rahman et al., 2012; van der Heijden et al., 2019). Symptomatic treatment often impairs a patient's quality of life and maltreatment; the untreated disease can lead to a fatal outcome (Greger et al., 2016). Moreover, delivery of universal healthcare is different in rural compared to urban settings regarding hospital size, the number of practitioners per capita, disease outcomes, and demographic characteristics of the patients admitted to these hospitals, which significantly impacts any disease outcome (Haque et al., 2020; Lim et al., 2017; National Research Council, 2013; Watkins et al., 2017). Socioeconomic developmental interventions are expected to enhance the marginalized communities financial ability increasing possibilities to improve their health-seeking behavior and access to healthcare and prevent diseases related to both morbidity and mortality (Ahmed et al., 2003; Institute of Medicine (US), 2008; Institute of Medicine, 2015; Kruk et al., 2018; Madhav et al., 2017; Makoge et al., 2017).

Reaching a confident preoperative diagnosis of acute appendicitis is difficult due to its varied presentation (Bhangu et al., 2015; Wagner et al., 2018). Appendicitis is relatively easy to diagnose and treat if presented early with typical symptoms, but various atypical symptoms may occur in extremes of age, making diagnosis and treatment challenging (Humes \& Simpson, 2006; Jones et al., 2021). Broadly, luminal occlusion and the subsequent bacterial infection initiate acute appendicitis (AlSalem, 2020; Song et al., 2018). It progresses to appendicular edema, which leads to distension of the appendix and vascular congestion, termed catarrhal appendicitis (Di Saverio et al., 2020). Further progression without intervention leads to phlegmonous appendicitis, gangrenous appendicitis, and ultimately perforated peritonitis (Alvarado, 2018). Delayed diagnosis and management of acute appendicitis have catastrophic consequences like intraabdominal sepsis, which increases mortality and morbidity (Balogun et al., 2019; Keyzer \& Gevenois, 2011). Patients from rural settings usually present with complications due to delayed presentation, negatively impacting treatment outcomes (Kucuk, 2015).

The disease profile of acute appendicitis varies markedly between the developed and developing world (Ferris et al., 2017; Kong et al., 2012, 2013; Markar et al., 2014). One South African study revealed that acute appendicitis is slightly more common in men. This study also revealed that the female sex and rural patients suffer the worst clinical outcomes, more extended hospital stay, and considerably significant health system burden (Kong et al., 2015). Since the disease's pathological progression is timedependent, prompt surgical care is crucial in reducing adverse outcomes and disease burden. Hence, ruptured appendicitis indicates poor access to healthcare and inequity in public health (Jablonski \& Guagliardo, 2005; Lee et al., 2010, 2011). The higher rate of complications, mortality, and increased healthcare expenditure is due to reluctant health-seeking behavior and lack of awareness in rural patients rather than a diagnostic dilemma, which can be presumably mitigated by public education (Latunji \& Akinyemi, 2018).

A substantial number of researches are conducted in Western and African countries on acute appendicitis (Kong et al., 2012, 2013, 2015). Multiple studies concern the geospatial association, risk factors associated with perforation, and appendicitis outcome (Ferris et al., 2017; Golz et al., 2020). Nevertheless, not much study was conducted among Bangladeshi appendicitis patients. As Bangladesh possesses unique population demography and different health system structure than the Western and African settings, this topic's study was critical and relevant. Therefore, this research group conducted a prospective observational study regarding appendicitis in a tertiary healthcare center in Bangladesh to understand better the nature of the disease and the consequences between urban and rural patients in this setting.

\section{Objectives of the study}

The study was conducted to explore the difference in consequences of acute appendicitis between urban and rural patients in terms of the time of presentation from the onset of symptoms, the clinical course of the disease at presentation, the attitude of the patient to surgical treatment, morbidity, mortality, and hospital stays of patients.

\section{Definition and diagnostic scoring of acute appendicitis}

In this study, several pieces of literature were reviewed. Among them, some critical works of literature and journal articles are pointed out. The appendix's sudden inflammation causes acute appendicitis, usually instigated by obstruction of the appendicular lumen, with subsequent invasion of the appendix wall by gut flora. As a result, it becomes inflamed and infected (Di Saverio et al., 2020; Hirsch, 2017). Several scoring systems like the Alvarado score, Pediatric Appendicitis Score, and Inflammatory Response Score helped make the clinical diagnosis of acute appendicitis (Andersson \& Andersson, 2008; Iftikhar et al., 2021; Pogorelić et al., 2015; Rajbhandari et al., 2020; Snyder et al., 2018; van Amstel et al., 2019; Vaziri et al., 2021).

\section{Presentation of acute appendicitis}

The most prevalent initial symptom was pain which was present in all the patients. Other common presentations were anorexia, nausea, headache, and constipation. Appendicular lump is found in delayed cases and can be confirmed by modern imaging, and intravenous antibiotics can be given if the patient is stable. Resolution of the inflammatory process can be reviewed by follow-up, and interval appendectomy may be needed in some cases. In elderly patients, acute appendicitis can be a sign of underlying malignancy (Keyzer \& Gevenois, 2011).

The lifetime incidence is approximately $10 \%$, and it is evident that the rate is increasing, which has drawn the interest of researchers in both the developed and the developing world (Anderson et al., 2012; Kong et al., 2012; Sallinen et al., 2016). The contrast in the focus of research has been observed between the developed and developing world. The developed world concentrates on the role of advanced imagining, conservative management, and the benefits of minimally invasive surgery, while the developing world is focusing on epidemiological and socioeconomic variation, risk factors with significant morbidity 
and mortality, and factors associated with access to healthcare (Clarke et al., 2013; Kong et al., 2013, 2014; Stengel et al., 2010). Clinical symptoms can be vague, elusive, and insufficient to differentiate between chronic and recurrent appendicitis, while the CT appearance is also indistinguishable from that of acute appendicitis (Drake et al., 2014). The conventional model of acute appendicitis shows that perforation can be prevented if appropriately intervened in time. However, a recent study has also focused on other factors, including male sex, advancing age, comorbidities, and inadequate health insurance (Sulu et al., 2010).

\section{Epidemiology of acute appendicitis}

Epidemiological studies suggest that the incidence of acute appendicitis peaks in children and adolescents, decreases with increasing age, and exhibits cultural, seasonal, and geospatial variation (Ahmed et al., 2018; AlHarmi et al., 2021; Fares, 2014; Totapally et al., 2020). The outcome of complicated appendicitis like abscess formation or peritonitis may result in generalized sepsis and death (Alvarado, 2018; Di Saverio et al., 2016). Hence, surgical intervention should be introduced within 36 hours from the onset of the symptom as delay causes worse outcomes in a complicated variant (Chen et al., 2015; Kim et al., 2016).

\section{Diagnostic dilemma of acute appendicitis}

Enteric infectious diseases that mimic acute appendicitis presentation, such as typhoid fever, amoebic dysentery, gastroenteritis, and helminths infestation, are endemic in this subregion, further complicating diagnosis and decision-making (Gardiner \& Gillespie, 2016). Significant positive correlations were observed with the rural population and higher primary appendectomy rates, negative appendectomy, and perforated appendicitis, explaining the geospatial linkage (Johnson, 2019; To \& Langer, 2010).

\section{MATERIALS AND METHODS}

\section{Study design}

This is a prospective analytical study.

\section{Place of Study}

This study was conducted in the General Surgery Units and Pediatric Surgery Unit of Chittagong Medical College Hospital in Chattogram, Bangladesh. This is a 1,000-bed tertiary hospital for Chittagong Division, with a catchment area covering around 10 million square feet.

\section{Period of Study}

The study lasted for a period of 6 months (April 26, 2016, to October 25, 2016).

\section{Study Population}

Patients with acute appendicitis admitted to the General Surgery Units and Pediatric Surgery Units of Chittagong Medical College Hospital, Bangladesh, were enrolled for the study.

\section{Sample Size}

The following standard formula was widely used in determining sample size. This study sequence is illustrated through a flowchart (Fig. 1).

$$
\begin{aligned}
n= & z^{2} p q / d^{2} \\
Z= & 1.96(\text { value of standard normal distribution) } \\
p= & 24.5 \%=0.245 \text { (prevalence) } \\
q= & 1-p=1-0.245=0.755 \\
e= & 10 \% \text { of prevalence }=0.1 \text { (allowable error) } \\
& (1.96)^{2} \times 0.25 \times 0.75 \\
n= & - \\
& (0.025)^{2} \\
N= & 1,200
\end{aligned}
$$

Nevertheless, due to time and financial constraints, a total of 200 patients, 100 on each arm, were selected as samples.

\section{Sampling}

sample.

The purposive sampling technique was used to select the

\section{Inclusion Criteria}

Patients with a clinical diagnosis of acute appendicitis at the General Surgery Units and Pediatric Surgery Unit of Chittagong Medical College Hospital during the study period were included.

\section{Exclusion Criteria}

Patients taking steroids and other immunosuppressive agents - (i) patients with ASA grade > II and (ii) patients unwilling to be enrolled - were excluded.

\section{Operational definition}

Acute Appendicitis

It is the acute inflammation of the vermiform appendix, usually resulting from bacterial infection.

\section{Urban- and Rural-Based Population}

(i) Patients hailing from within the Chattogram City Corporation area were considered urban patients. (ii) Patients hailing from outside Chattogram City Corporation area dependent on agriculture were considered rural patients.

\section{Consequences}

The consequences include the clinical course of the disease at presentation, the outcome of postoperative patients, hospital stay, and mortality in patients with acute appendicitis

\section{Data collection procedure}

This is a prospective analytical study of patients diagnosed with acute appendicitis at the General Surgery and Pediatric Surgery Ward, Chittagong Medical College Hospital, from April 2016 to October 2016. The diagnosis was confirmed by clinical evidence and per-operative findings. Patients of acute appendicitis fulfilling inclusion and were included in this study. Attending physicians in the surgery ward would evaluate patients just after admission. He/she would then inform the physician conducting the study about the patient. Diagnosis and demographic clinical variables were made based on the patient's statement, the attendant's statement, clinical examination, and available records. After fulfilling the inclusion criteria, patients were enrolled with a unique ID. Subjects were briefed about the study's objectives, risks, benefits, freedom to participate in the survey, and confidentiality. 


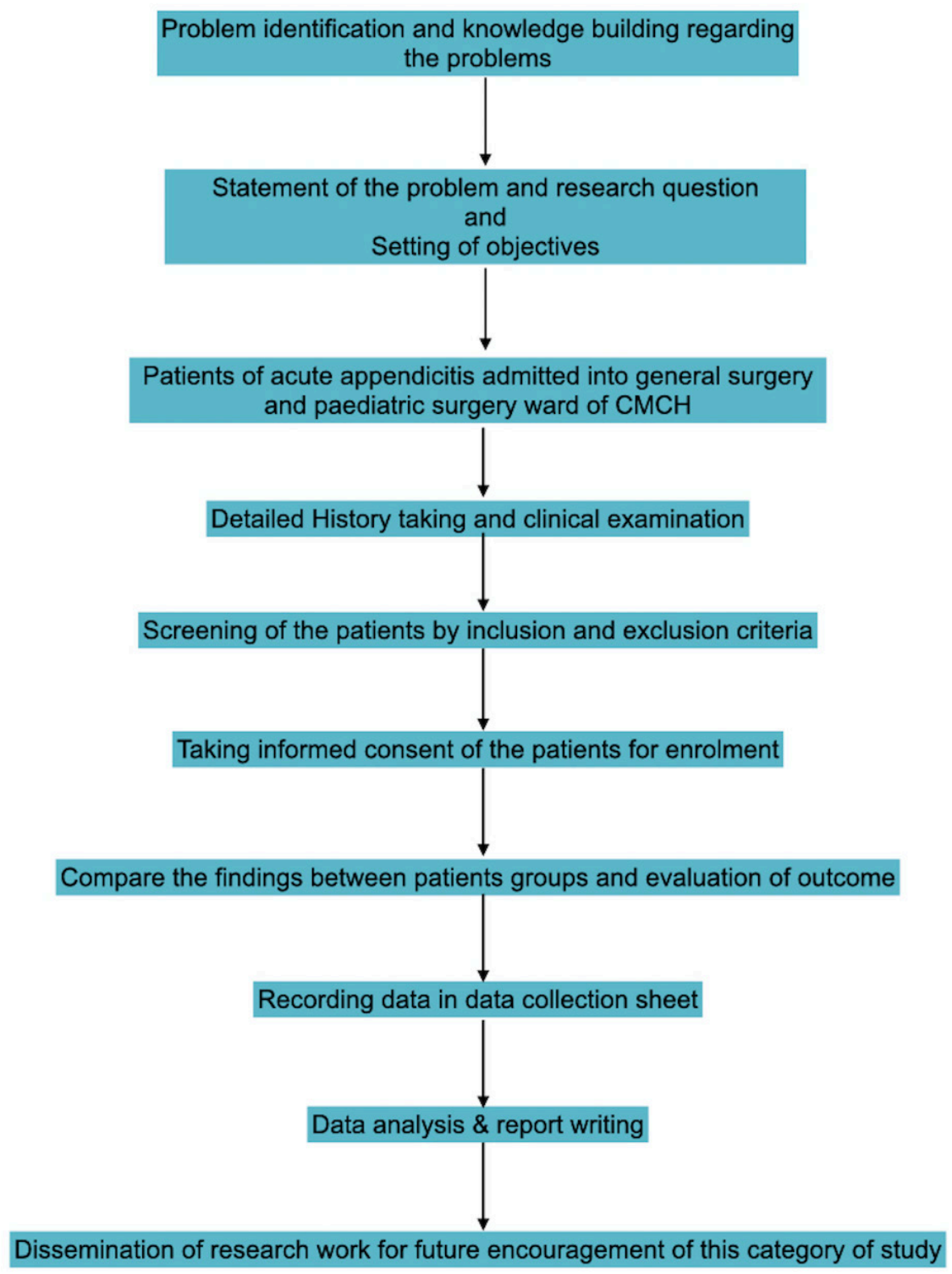

Figure 1. A flowchart demonstrating the arrangement of this research.

Informed consent was obtained accordingly. The study physician herself filled up the prestructured case record form. The case definition of the operational variable had been described. Patient data such as age, sex, signs, symptoms on presentation, duration of symptoms, physical findings, diagnostic modalities, and surgical findings were noted. This questionnaire was used for the collection of information by interviewing patients. All the collected data from the questionnaire was checked very carefully to identify errors in collecting data. Data-processing work consisted of registration of schedules, editing, coding and computerization, dummy tables, analysis, and matching data. The technical matters of editing, encoding, and computerization were looked at by the researcher.

\section{Main outcome variables}

An interview-based questionnaire was used to collect information from the patients regarding age, sex, demographic characteristics, and others. Clinical variables were time elapsed since the onset of symptoms, the clinical course of the disease at presentation, attitude towards surgical treatment, morbidity (uneventful, wound infection, peritonitis, ileus, pneumonia, acute renal failure, septic shock, relaparotomy, etc.), hospital stay, and mortality.

\section{Data analysis}

Data for socio-demographic and clinical variables were obtained from all participants using a predesigned and easily understandable questionnaire. After collecting all information, these data were checked, verified for consistency, and edited for the finalized result. After editing and coding, the coded data were directly entered into the computer using Statistical Package for the Social Sciences (SPSS) version 21. Data-cleaning validation and analysis were carried out using the SPSS PC software and graphs and charts by MS Excel. The result was presented in tables. A $p$-value $<0.5$ is considered significant. 


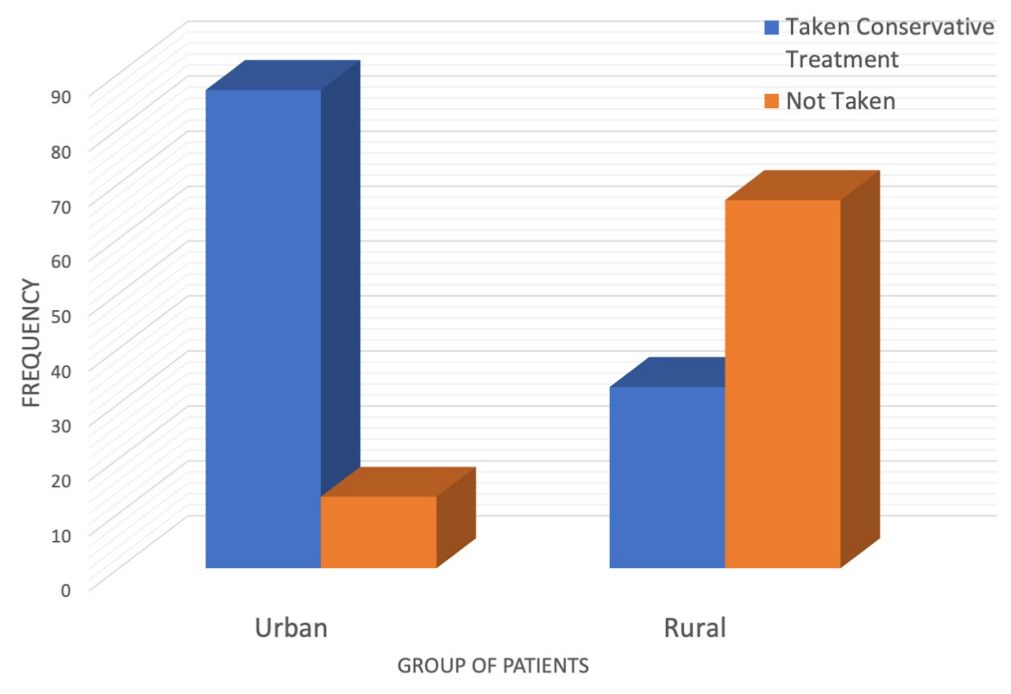

Figure 2. Two different research groups depending on the area of the study.

\section{Quality assurance strategy}

To ensure good quality of the data collection procedure, an operating manual was first made. Then a sample size was selected. Next, a standard questionnaire was developed. Then the questionnaire was pretested. The pretest ensures that the respondents can understand the questionnaire and answer accordingly.

\section{Ethical approval}

This study received ethical approval (Reference No.: CMC/PG/2016/265, Dated February 16, 2016) from the Institutional Review Board of Chittagong Medical College Hospital (CMCH) 57 K.B. Fazlul Kader Rd, Chattogram 4203, Bangladesh.

\section{Methodology proper}

I. This study was done in all units of General and Pediatric Surgery wards in $\mathrm{CMCH}$.

II. Pretesting of the questionnaire.

III. Finalization of the questionnaire.

IV. Consecutive sampling.

V. Consent taking.

VI. Detailed history.

VII. Physical examination.

VIII. Investigation.

IX. Filling the questionnaire by data collected from patients.

\section{RESULTS}

The maximum number of patients, $33.5 \%$, was between the age group of 21 and 30 years. The patient's mean age was $23.37 \pm 11.54$ years and $25.69 \pm 11.34$ years in the urban and rural groups, respectively (Fig. 2). Out of 200 cases, 132 $(66.0 \%)$ patients were male and $68(34.0 \%)$ were female. The male:female ratio was 1.94:1. The maximum numbers of patients' education status were below secondary school certificate $(45$; $22.5 \%)$ and higher-secondary school certificate $(32 ; 16.0 \%)$. The maximum numbers of illiterate patients $(27 \%)$ were from rural areas. Among the urban patients, $45 \%$ came from a middle class of socioeconomic background and they account for the major percentage of total participants enrolled, followed by $34 \%$ lower class and $21 \%$ upper class (Fig. 3). In rural patients, $47 \%$ of patients had a poor socioeconomic background, and the remaining $36 \%$ and $17 \%$ came from the middle and high class, respectively (Table 1$)$.

The majority $(52 \%)$ of the research respondents of rural areas habituate daily vegetable consumption (Table 2). Only $34 \%$ of urban patients took vegetables daily in their dietary practice. The proportion of daily meat consumption was observed in $29 \%$ urban patients and 24\% rural patients. Regular bowel habit was found in $49 \%$ of urban and $86 \%$ of rural patients, respectively. Constipation was observed in $51 \%$ of urban and $14 \%$ of rural patients, respectively. The result is significant at $p<0.05$.

It was found that $87 \%$ of urban patients and only $33 \%$ of rural patients had taken conservative treatment before hospitalization in $\mathrm{CMCH}$. The mean time elapsed since the onset of symptoms was $2.96 \pm 1.17$ days in urban patients and $8.41 \pm$ 2.437 days in rural patients. Patients with acute appendicitis that presented in the emergency ward within the first day of the onset of symptoms were only $5.5 \%$ : the majority of rural group patients presented on days $4-6$, i.e., $46 \%$ of rural patients. The $p$-value is 0.007 which is significant. In this study, $59 \%$ of urban patients and $45 \%$ of rural patients required appendectomy. $26 \%$ of urban patients and $37 \%$ of rural patients required appendectomy with toileting. $5 \%$ of urban patients and $11 \%$ of rural patients required laparotomy with appendectomy and toileting. 10\% of urban patients and $7 \%$ of rural patients received conservative treatment. The $p$-value is $<0.00001$, which is significant. About $74.11 \%$ of rural patients and $30 \%$ of urban patients said they disagree with operative treatment. After proper explanation and counseling, they gave consent to surgery. The $p$-value is $<0.00001$ which is significant. In preoperative evaluation, inflamed appendicitis was present in $68 \%$ of urban and $40 \%$ of rural patients. Perforation was found in $17.78 \%$ of urban and $33.33 \%$ of rural patients. Generalized peritonitis was observed in $3.33 \%$ of urban and $11.83 \%$ of rural 


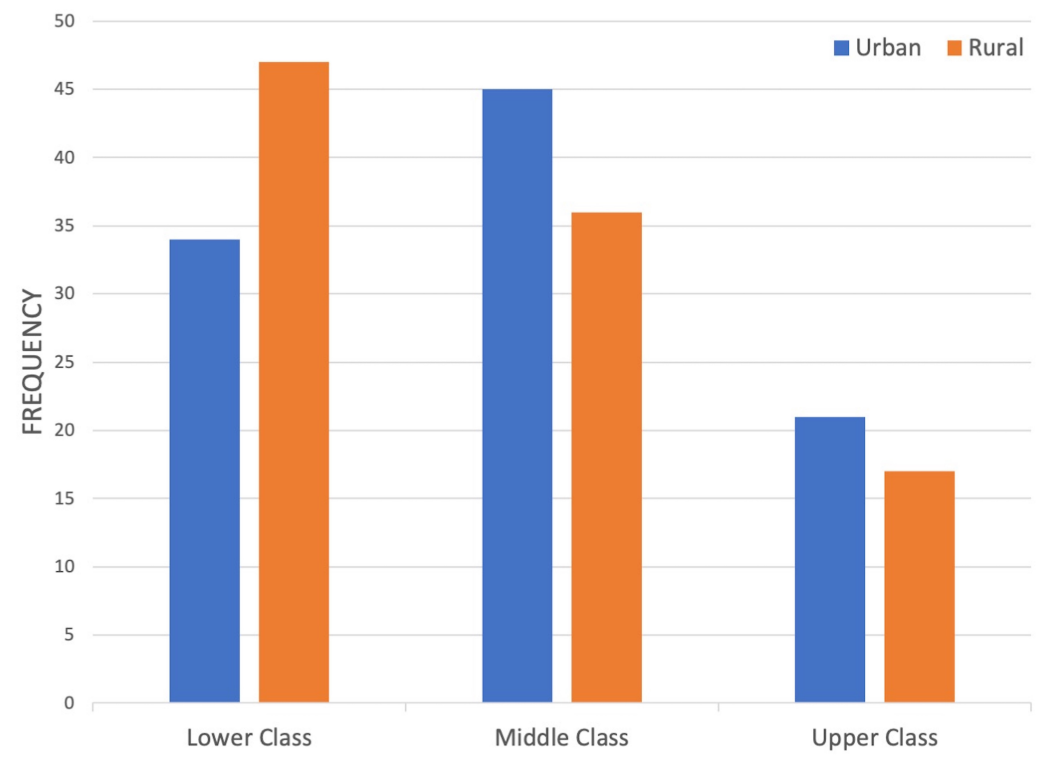

Figure 3. Three different groups depending on financial ability.

Table 1. Socio-demography of the research participants $(n=200)$.

\begin{tabular}{lccc}
\hline \multirow{2}{*}{ Age (years) } & \multicolumn{2}{c}{ Frequency } & \multirow{2}{*}{ Total (\%) } \\
\cline { 2 - 3 }$\leq 10$ & Urban $(\boldsymbol{n}=\mathbf{1 0 0})$ & Rural $(\boldsymbol{n}=\mathbf{1 0 0})$ & $16(8)$ \\
$11-20$ & 10 & 6 & $49(24.5)$ \\
$21-30$ & 25 & 24 & $67(33.5)$ \\
$31-40$ & 31 & 36 & $47(23.5)$ \\
$>40$ & 22 & 25 & $21(10.5)$ \\
Mean \pm SD & 12 & 9 & \\
Gender & $25.69 \pm 11.34$ & & $132(66)$ \\
Male & & $33(48.53)$ & $68(34)$ \\
Female & $65(49.25)$ & & \\
Male:female & $35(51.47)$ & 27.54 & \\
Education & & 32 & $41(20.5)$ \\
Illiterate & 14 & 18 & $57(28.5)$ \\
Class (I-IX) & 25 & 20 & $45(22.5)$ \\
SSC & 27 & 3 & $32(16.0)$ \\
HSC & 12 & 0 & $18(9.0)$ \\
Graduate & 15 & & $7(3.5)$ \\
Postgraduate & 7 & &
\end{tabular}

patients, gangrenous appendicitis was present in $12.22 \%$ of urban and $66.67 \%$ of rural patients, obstruction of lumen due to fecalith was found in $68 \%$ of urban and $75 \%$ of rural patients, and pelvic abscess was present in $7.78 \%$ of urban and $20.43 \%$ of rural patients (Fig. 4). Among 183 patients, 75 (40.98\%) patients were uneventful and recovered without any complication (Fig. 5). On the other hand, 108 (59.02\%) patients with appendicitis developed complications after operations. Compared with urban patients, rural patients suffered more complications like wound infection
(34.4\% and $68.4 \%$, resp.), postoperative ileus $(6.3 \%$ and $38.2 \%$, resp.), peritonitis $(12.5 \%$ and $25 \%$, resp.), septic shock $(0 \%$ and $7.9 \%$, resp.), burst abdomen ( $0 \%$ and $5.3 \%$, resp.), and acute renal failure ( $0 \%$ and $2.6 \%$, resp.) (Fig. 6). The mean hospital stay was $4.37 \pm 1.69$ days in urban and $8.41 \pm 2.44$ days in rural patients. Thirty-two urban and 74 rural patients had a complicated recovery. The mortality rate was $2 \%$ in rural areas, while in the urban setting no patients died (Table 3 ). In a stepwise linear regression model for the variables, the variance in the treatment outcome can be 
Table 2. Dietary practice and bowel habit of the research participants $(n=200)$.

\begin{tabular}{lccc}
\hline Variable & \multicolumn{2}{c}{ Frequency } & Total (\%) \\
\cline { 1 - 2 } The dietary practice of the participants & Urban $(\boldsymbol{n}=\mathbf{1 0 0})$ & Rural $(\boldsymbol{n}=\mathbf{1 0 0})$ & \\
\cline { 2 - 3 } Daily vegetable consumption & 34 & 52 & $86(43)$ \\
No vegetable/fruits consumption & 66 & 48 & $114(57)$ \\
Daily meat consumption & 29 & 24 & $53(26.5)$ \\
Bowel habit of the participants & & & $135(67.5)$ \\
Regular bowel habit & 49 & 86 & $65(32.5)$ \\
Constipation & 51 & 14 & 0.000 \\
\hline
\end{tabular}

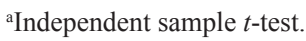

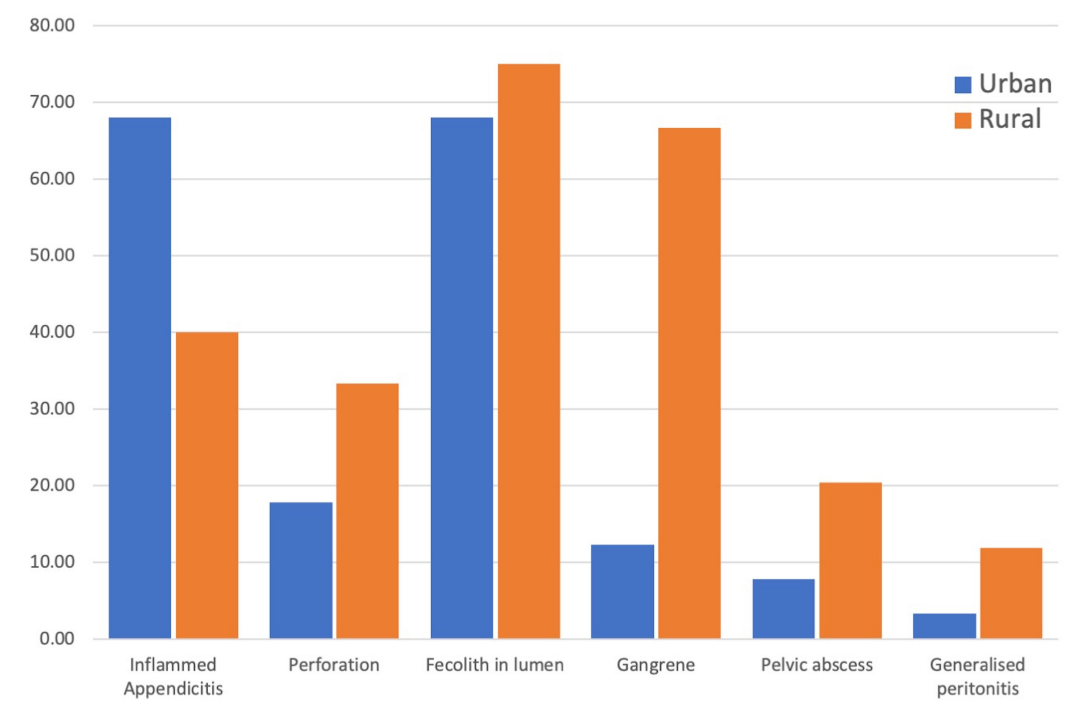

Figure 4. The clinical consequences of appendicitis with dwelling practice.

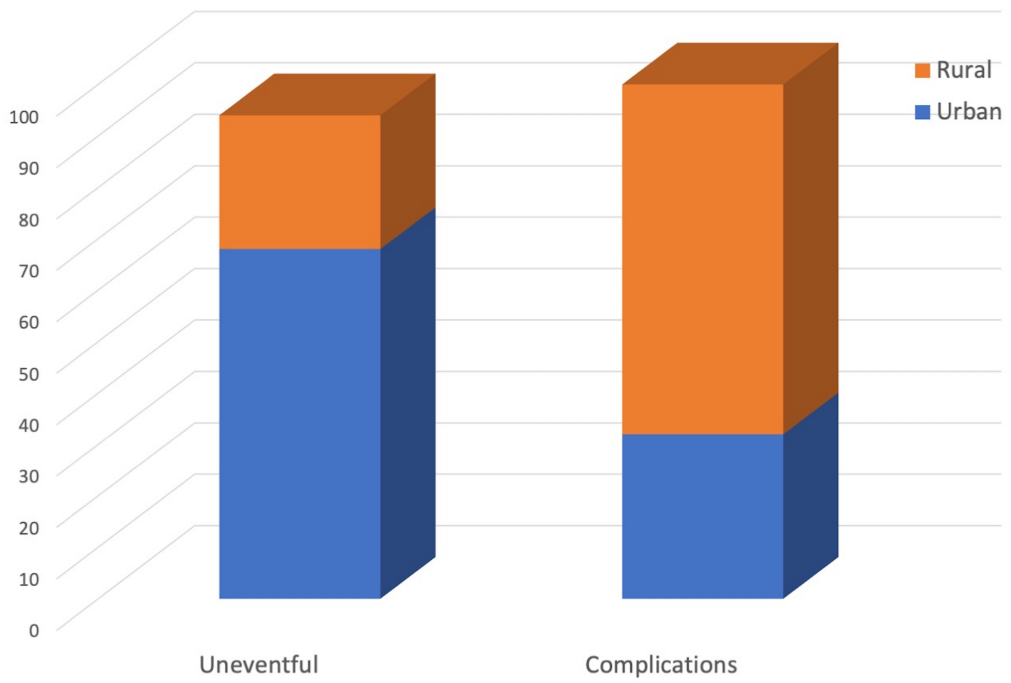

Figure 5. The surgical outcome of appendicitis with dwelling practice. 
explained up to $19.9 \%$ by the location variables (urban or rural); on the contrary, other variables (sex, socioeconomic status, educational qualification, dietary habit, bowel habit, prehospital treatment, etc.) were not found significant and were left out of the model. The overall picture of appendicitis in Bangladesh is shown in Figure 7.

\section{DISCUSSION}

The study's objective was to explore differences in the consequences of acute appendicitis between the two arms of the study: urban patients $(n=100)$ and rural patients $(n=100)$. Rural patients were observed to have the worse outcomes or consequences from acute appendicitis than urban patients. This study's overall finding is similar to studies conducted in other low- and middle-income countries across different subclasses of patients (Elliott et al., 2019; Hernandez et al., 2017, 2018).

The study was conducted in the General and Pediatric Surgery Department of Chittagong Medical College Hospital for over 6 months on 200 patients with a clinical diagnosis of acute appendicitis. The highest number of the patients was between the age group of 21 and 30 years, with a similar mean age in the urban and rural groups. The overall incidence of disease increases during the younger and teenage period and then gradually decreases. Moreover, a definite male predominance was seen in the patient groups with an overall male:female ratio of 1.94:1. The incidence of acute appendicitis usually occurs in the second or third decade of life, and the disease is less common at both extremes of age. Most studies show a slight male predominance over females (Bhangu et al., 2015; Hernandez et al., 2018). Studies in other countries also demonstrated similar demographic attributes of the urban and rural patient groups (Ayoade et al., 2006; Hernandez et al., 2018; Kong et al., 2013, 2015).

The present study shows that most rural area respondents are habituated to daily vegetable consumption, which is not seen in urban groups' dietary practices. Moreover, the proportion of daily meat consumption was also higher in the urban population. Regular bowel habit was seen in preponderance in the rural patients compared to the urban patients (86\% vs. 49\%). Consequently, constipation was prevalent in the urban patients' group with $51 \%$ and $14 \%$, respectively $(p<0.05)$. These findings are consistent with several other studies. For example, a theory depicted that people adapt Westernized diet, reducing roughage and sedentary life among urban patients increases the risk (Lin et al., 2015a). Also, several studies revealed that fecalith, one of the leading causes of appendicitis, is also linked to a low-fiber diet (Damanik et al., 2016).

Our study reveals that most urban patients were from the middle socioeconomic class, followed by the lower and upper levels. However, the majority of the rural patients were from lower socioeconomic classes. In addition, other studies reported that the overall incidence of appendicitis and perforated appendicitis was significantly higher in the low-income population than in the average income population, which is attributed to a higher risk of appendicitis, associated hospital costs, and length of hospital stay due to appendectomy for the low-income patients (Kong et al., 2013; Lin et al., 2015b).

A significant percentage of the urban patients had taken conservative treatment before hospitalization, contrary to the rural patients $(p<0.05)$. Moreover, we observed that the mean duration or presentation was delayed as it is almost doubled in rural patients compared to the urban group. This indicates poor access to healthcare in rural areas. A small percentage $(5.5 \%)$ of patients with acute appendicitis presented to the emergency ward within the first day of the onset of symptoms. Likewise, many patients (46\%) from rural groups presented on the 4th to 6th day since the onset of symptoms. The result is significant at $p<0.05$. The delay in hospitalization augments the worsening of the disease and development of complications and ultimately poor outcomes.

On the other hand, patients hailing from urban areas presented to the hospital as soon as possible after signs and symptoms developed. Findings are similar to other reports. In South Africa, delayed presentation is a recurring theme that explains the country's high perforation rates (Hernandez et al., 2018; Kong et al., 2013, 2015). Moreover, a significant percentage

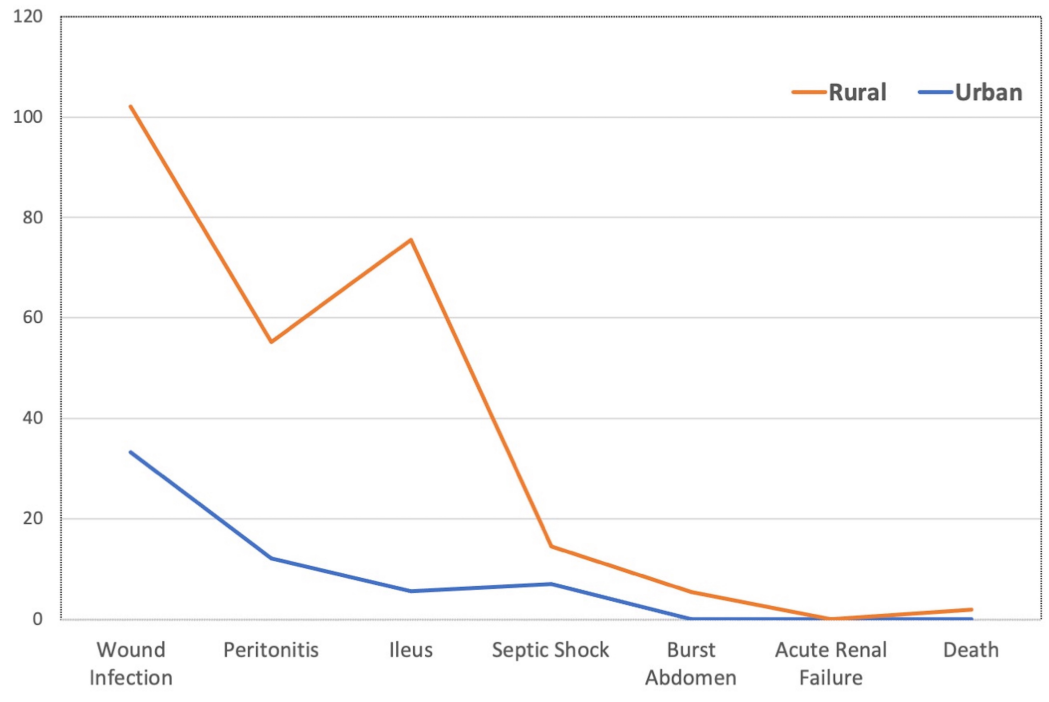

Figure 6. The complication of appendicitis with dwelling practice. 
Table 3. Time elapsed since the onset of the symptoms, treatment for the patients with acute appendicitis, attitude toward surgical treatment $(n=183)$, mean hospital stays $(n=200)$, and outcome of treatment $(n=108)$.

\begin{tabular}{|c|c|c|c|c|}
\hline \multirow{2}{*}{ Time elapsed since the onset of symptoms $(n=200)^{\mathrm{a}}$} & \multicolumn{2}{|c|}{ Frequency } & \multirow{2}{*}{ Total (\%) } & \multirow{2}{*}{$p$-value } \\
\hline & Urban $(n=100)$ & Rural $(n=100)$ & & \\
\hline$<1$ day & 9 & 2 & $11(5.5)$ & \\
\hline 1-3 days & 46 & 33 & $79(39.5)$ & \\
\hline 4-6 days & 37 & 46 & $83(41.5)$ & 0.000 \\
\hline$>6$ days & 8 & 19 & $27(13.5)$ & \\
\hline Mean \pm SD & $2.96 \pm 1.88$ & $5.28 \pm 2.8$ & & \\
\hline $\begin{array}{l}\text { Treatment for the patients with acute appendicitis }(n= \\
200)^{\mathrm{b}}\end{array}$ & $\operatorname{Urban}(n=100)$ & $\operatorname{Rural}(n=100)$ & & \\
\hline Appendectomy (conventional approach) & 59 & 45 & & \\
\hline Appendectomy with toileting & 26 & 37 & & \\
\hline $\begin{array}{l}\text { Exploratory laparotomy with appendectomy and } \\
\text { toileting }\end{array}$ & 5 & 11 & & \\
\hline Conservative (Appendicular lump) & 10 & 7 & & \\
\hline \multirow{2}{*}{ Attitude for surgical treatment $(n=183)^{\mathrm{c}}$} & \multicolumn{2}{|c|}{ Frequency } & \multirow{2}{*}{\multicolumn{2}{|c|}{$p$-value }} \\
\hline & Urban $(\%)(n=90)$ & Rural $(\%)(n=93)$ & & \\
\hline Consented immediately & $63(70)$ & $24(25.8)$ & & \\
\hline Consenting delayed & $27(30)$ & $69(74.2)$ & & \\
\hline \multirow{2}{*}{ Mean hospital stay $(n=200)$} & \multicolumn{2}{|c|}{ Mean days } & & \\
\hline & Urban $(n=100)$ & Rural $(n=100)$ & & \\
\hline Hospital Stay & $4.37 \pm 1.692$ & $8.41 \pm 2.437$ & & \\
\hline \multirow{2}{*}{$\begin{array}{l}\text { The outcome of treatment who developed complications } \\
\text { following surgery }(n=108)\end{array}$} & \multicolumn{2}{|c|}{ Number of cases } & & \\
\hline & $\operatorname{Urban}(n=32)$ & $\operatorname{Rural}(n=76)$ & & \\
\hline Complicated with recovery & 32 & 74 & \\
\hline Expired & 0 & 2 & & \\
\hline
\end{tabular}

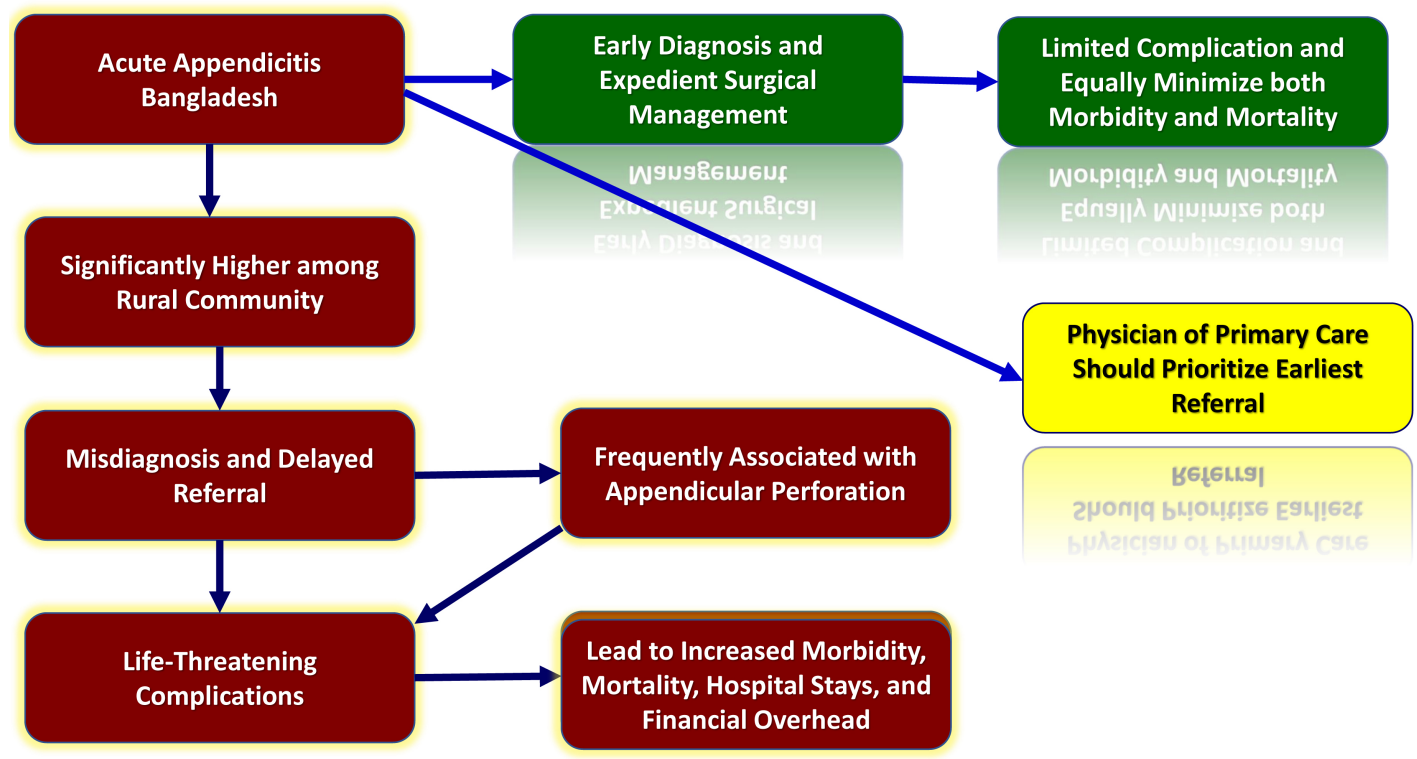

Figure 7. The overall picture of appendicitis in Bangladesh. 
of rural patients initially disagreed with consenting for operative treatment, which is higher than in the urban group $(74.2 \% v s$. $30 \%)$. However, they agreed to surgery after proper explanation and counseling. This was also reflected in the higher percentage of urban patients consenting immediately to surgery compared to the rural group ( $70 \%$ vs. $25.8 \%)$.

The per-operative evaluation revealed that perforation, gangrene, pelvic abscess, and generalized peritonitis were significantly predominant in rural patients $(p<0.05)$. This might be contributed to by very late presentation, misdiagnosis, or maltreatment in the rural group. However, in the urban group, inflamed appendicitis was more prevalent. Patients living in rural areas experienced delayed referrals and complications, mainly contributed to by illiteracy, ignorance, and financial constraints. Delayed referrals caused 236 children to present with lifethreatening preoperative complications such as appendicular abscess, appendicular mass, perforation, gangrene, and peritonitis, which were evident during exploratory laparotomy. The children who presented early and who presented late showed a significant statistical difference due to delayed presentation, which caused postoperative complications (Elliott et al., 2019; Hernandez et al., 2018; Kim et al., 2016). Some studies support our observation as well.

More urban patients required appendectomy (59\% vs. $45 \%$ ), while $37 \%$ of the rural patients required appendectomy with toileting compared to $26 \%$ of the urban patients. This preponderance was observed in more rural patients requiring exploratory laparotomy with appendectomy and toileting (11\% vs. $5 \%$ ). However, $12 \%$ of urban patients and $5 \%$ of rural patients received conservative treatment. The result is significant at $p<$ 0.05 . Other authors also reported a similar preponderance of complicated procedures in the rural population (Hernandez et al., 2018; Kong et al., 2015).

Proper workup and evaluation were ensured in all patients. The occurrence of any adverse events is managed immediately. Bowel sound, flatus passage, hospital stays, and lump resolution were observed. The urban residents showed a higher percentage of the uneventful recovery. In comparison, in rural patients, the rates of postoperative complications like wound infection, postoperative ileus, burst abdomen, septic shock, acute renal failure, and death were higher. Mean hospital stay was higher in rural patients than urban patients $(8.41 \pm 2.44$ days $v s .4 .37 \pm$ 1.69 days). This might have significantly reduced hospital stayassociated costs in urban patients (Gardiner \& Gillespie, 2016). The scenario is quite similar in rural South Africa, with significant morbidity due to prolonged delays before definitive surgical care (Kong et al., 2015). Delayed presentation to the healthcare facilities was the most closely associated variable with poor outcomes from intra-abdominal sepsis, implying a direct causal relationship (Narsule et al., 2011; Sartelli et al., 2011). Strategic interventions should be designed to reduce delays to definitive care to lessen the complications associated with acute appendicitis. A significant delay between the onset of symptoms and the patient seeking healthcare can be pronounced by delayed recognition for surgical care and subsequent logistical delays in transferring the patient to the tertiary hospital (Kong et al., 2014). However, the patient might delay receiving definitive surgical treatment despite timely presentation to the healthcare facility due to misdiagnoses. The racial variation in acute appendicitis presentation makes the diagnosis difficult, as the diagnosis is mainly clinical (Livingston \& Fairlie, 2012).

All patients were compliant with the proposed postoperative surveillance protocol. The total follow-up duration was from 4 to 12 days in the whole series. The study shows that 98 rural and 100 urban patients recovered. The mortality rate evaluation was $2 \%$ in the rural subjects, but in the urban setting no patients expired. The patients died due to intra-abdominal sepsis complications, presented as septic shock, which subsequently developed into multiple-organ disorder syndrome, leading to death.

\section{Limitations of the study}

This study was not without limitations. The limitations of the studies were as follows:

- The sample size of the study population was small.

- It was a single-center study. Only patients admitted to $\mathrm{CMCH}$ were considered for the task. Therefore, this does not reflect the overall picture of the country. A large-scale study needs to be conducted to reach a definitive conclusion.

- The study duration was short.

- The study was conducted in a tertiary care hospital which may not represent a primary or secondary center.

- The same surgeons did not do the surgeries.

- All the units of this hospital did not follow uniform management protocol.

- The sample was taken by the purposive method, in which questions of personal biases might arise.

\section{CONCLUSIONS}

In conclusion, the complications and adverse outcomes of appendicitis are higher among Bangladesh's rural population. The number of cases treated in this study was found to face these crises due to misdiagnosis and delayed referral, which caused life-threatening complications. If acute appendicitis is diagnosed early and surgical management conducted, then usually outcomes have minimum difficulties. In rural populations, disease presentation is late and is associated with a high perforation rate, translating into increased morbidity and even mortality. Once acute appendicitis is diagnosed, expedient surgery and appropriate perioperative antibiotics can minimize morbidity and mortality. Caregivers should be suspicious of appendicitis and present patients with abdominal pain to the hospital early. Physicians in primary/secondary level healthcare centers should prioritize appendicitis and refer patients before surgical consultation. Early and accurate management can reduce the burden of the disease.

\section{RECOMMENDATIONS}

- In addition to early and accurate diagnosis of disease, evaluation of the condition, and setting a plan for proper management, the following recommendations should be considered:

- Diagnosis of the disease should be based mainly on the history, with examination and USG being used to exclude other differential diagnoses and to evaluate the condition. 
- Early diagnosis and prompt treatment are necessary for patients with suspected appendicitis to avoid morbidity and mortality.

- Patients diagnosed outside the tertiary level hospital should be referred early to a tertiary center, if there is no operative facility in a rural setting.

- Patients with complicated appendicitis should be strictly monitored and managed accordingly in the postoperative period to avoid complications.

\section{ACKNOWLEDGMENTS}

The authors wish to extend special gratitude to all staff and faculty of the Department of Surgery and the Department of Pediatric Surgery at Chattogram Medical College Hospital.

\section{AUTHORS' CONTRIBUTION}

All authors made significant contributions to the work reported, whether that is in the conception, study design, execution, acquisition of data, analysis, and interpretation, or in all these areas; took part in drafting, revising, or critically reviewing the article; gave final approval for the version to be published; have agreed on the journal to which the essay has been submitted; and agreed to be accountable for all aspects of the work.

\section{CONSENT FOR PUBLICATION}

All authors reviewed and approved the final version and have agreed to be accountable for all aspects of the work, including any issues related to accuracy or integrity.

\section{DISCLOSURE}

The authors declare that they do not have any financial involvement or affiliations with any organization, association, or entity directly or indirectly with the subject matter or materials presented in this article. This also includes honoraria, expert testimony, employment, ownership of stocks or options, patents or grants received or pending, or royalties.

\section{CONFLICT OF INTEREST}

\section{None.}

\section{FUNDING}

This paper was not funded.

\section{REFERENCES}

Ahmed SM, Adams A, Chowdhury A, Bhuiya A. Ahmed SM, Adams AM, Chowdhury M, Bhuiya A. Changing health-seeking behavior in matlab, Bangladesh: do development interventions matter? Health Policy Plan, 2003; 18:306-15.

Ahmed W, Akhtar MS, Khan S. Seasonal variation of acute appendicitis. Pak J Med Sci, 2018; 34(3):564-7; doi:10.12669/ pjms.343.14793

AlHarmi RAR, Almahari SA, AlAradi J, Alqaseer A, AlJirdabi NS, Ahmed FA. Seasonal variation in cases of acute appendicitis. Surg Res Pract, 2021; 2021:8811898; doi:10.1155/2021/8811898

Allender S, Foster C, Hutchinson L, Arambepola C. Quantification of urbanization in relation to chronic diseases in developing countries: a systematic review. J Urban Health, 2008; 85(6):938-51; doi:10.1007/s11524-008-9325-4

Al-Salem AH. Acute appendicitis. In: Al-Salem AH (ed.). Atlas of pediatric surgery. Springer, Cham, Switzerland, pp. 257-62, 2020; doi:10.1007/978-3-030-29211-9_29
Al-Shoaibi AAA, Matsuyama A, Khalequzzaman M, Haseen F, Choudhury SR, Hoque BA, Chiang C, Hirakawa Y, Yatsuya H, Aoyama A. Perceptions and behavior related to noncommunicable diseases among slum dwellers in a rapidly urbanizing city, Dhaka, Bangladesh: a qualitative study. Nagoya J Med Sci, 2018; 80(4):559-69; doi:10.18999/ nagjms.80.4.559

Alvarado A. Clinical approach in the diagnosis of acute appendicitis. IntechOpen, London, UK, 2018. Available via https://www. intechopen.com/books/current-issues-in-the-diagnostics-and-treatment-ofacute-appendicitis/clinical-approach-in-the-diagnosis-of-acute-appendicitis (Accessed 16 June 2021)

Anderson JE, Bickler SW, Chang DC, Talamini MA. Examining a common disease with unknown etiology: trends in epidemiology and surgical management of appendicitis in California, 1995-2009. World J Surg, 2012; 36(12):2787-94; doi:10.1007/s00268-012-1749-z

Andersson M, Andersson RE. The appendicitis inflammatory response score: a tool for the diagnosis of acute appendicitis that outperforms the Alvarado score. World J Surg, 2008; 32(8):1843-9; doi:10.1007/s00268008-9649-y

Ayoade BA, Olawoye OA, Salami BA, Banjo AA. Acute appendicitis in Olabisi Onabanjo University Teaching Hospital Sagamu, a three-year review. Niger J Clin Pract, 2006; 9(1):52-6.

Balogun OS, Osinowo A, Afolayan M, Olajide T, Lawal A, Adesanya A. Acute perforated appendicitis in adults: management and complications in Lagos, Nigeria. Ann Afr Med, 2019; 18(1):36-41.

Bashar MK, Alam MZ, Aziz MM, Nur-E-Elahi M, Taher MA, Jahan I. Laparoscopic-assisted appendicectomy in District Hospital, Joypurhat, Bangladesh. Mymensingh Med J, 2014; 23(1):130-6.

Bhangu A, Søreide K, Di Saverio S, Assarsson JH, Drake FT. Acute appendicitis: modern understanding of pathogenesis, diagnosis, and management. Lancet, 2015; 386(10000):1278-87; doi:10.1016/S01406736(15)00275-5.

Boland PA, Donlon NE, Kelly ME, Nugent T, Free R, Waters P, Neary P, Rausa E, Proud D, Donohoe CL, Barry KM, Reynolds JV. Current opinions and practices for the management of acute appendicitis: an international survey. Ir J Med Sci, 2021; 190(2):749-54; doi:10.1007/ s11845-020-02349-6

Chen CC, Ting CT, Tsai MJ, Hsu WC, Chen PC, Lee MD, Liu MH, Shih HC. Appendectomy timing: will delayed surgery increase the complications? J Chin Med Assoc, 2015; 78(7):395-9; doi:10.1016/j. jcma.2015.04.001

Clarke DL, Kong VY, Handley J, Aldous C. A concept paper: using the outcomes of common surgical conditions as quality metrics to benchmark district surgical services in South Africa as part of a systematic quality improvement program. S Afr J Surg, 2013; 51(3):84-6; doi:10.7196/ sajs.1476

Damanik B, Fikri E, Nasution IP. Relation between fiber diet and appendicitis incidence in children at H. Adam Malik Central Hospital, Medan, North Sumatra-Indonesia. Bali Med J, 2016; 5(2):84.

Di Saverio S, Birindelli A, Kelly MD, Catena F, Weber DG, Sartelli M, Sugrue M, De Moya M, Gomes CA, Bhangu A, Agresta F, Moore EE, Soreide K, Griffiths E, De Castro S, Kashuk J, Kluger Y, Leppaniemi A, Ansaloni L, Andersson M, Coccolini F, Coimbra R, Gurusamy KS, Campanile FC, Biffl W, Chiara O, Moore F, Peitzman AB, Fraga GP, Costa D, Maier RV, Rizoli S, Balogh ZJ, Bendinelli C, Cirocchi R, Tonini V, Piccinini A, Tugnoli G, Jovine E, Persiani R, Biondi A, Scalea T, Stahel P, Ivatury R, Velmahos G, Andersson R. WSES Jerusalem guidelines for diagnosis and treatment of acute appendicitis. World J Emerg Surg, 2016; 11:34; doi:10.1186/s13017-016-0090-5

Di Saverio S, Podda M, De Simone B, Ceresoli M, Augustin G, Gori A, Boermeester M, Sartelli M, Coccolini F, Tarasconi A, De' Angelis N, Weber DG, Tolonen M, Birindelli A, Biffl W, Moore EE, Kelly M, Soreide K, Kashuk J, Ten Broek R, Gomes CA, Sugrue M, Davies RJ, Damaskos D, Leppäniemi A, Kirkpatrick A, Peitzman AB, Fraga GP, Maier RV, Coimbra R, Chiarugi M, Sganga G, Pisanu A, De’ Angelis GL, Tan E, Van Goor 
H, Pata F, Di Carlo I, Chiara O, Litvin A, Campanile FC, Sakakushev B, Tomadze G, Demetrashvili Z, Latifi R, Abu-Zidan F, Romeo O, SegoviaLohse H, Baiocchi G, Costa D, Rizoli S, Balogh ZJ, Bendinelli C, Scalea T, Ivatury R, Velmahos G, Andersson R, Kluger Y, Ansaloni L, Catena F. Diagnosis and treatment of acute appendicitis: 2020 update of the WSES Jerusalem guidelines. World J Emerg Surg, 2020; 15(1):27; doi:10.1186/ s13017-020-00306-3

Drake FT, Mottey NE, Farrokhi ET, Florence MG, Johnson MG, Mock C, Steele SR, Thirlby RC, Flum DR. Time to appendectomy and risk of perforation in acute appendicitis. JAMA Surg, 2014; 149(8):837-44; doi:10.1001/jamasurg.2014.77

Elliott BM, Witcomb Cahill H, Harmston C. Paediatric appendicitis: increased disease severity and complication rates in rural children. ANZ J Surg, 2019; 89(9):1126-32; doi:10.1111/ans.15328

Fares A. Summer appendicitis. Ann Med Health Sci Res, 2014; 4(1):18-21; doi:10.4103/2141-9248.126603

Ferris M, Quan S, Kaplan BS, Molodecky N, Ball CG, Chernoff GW, Bhala N, Ghosh S, Dixon E, Ng S, Kaplan GG. The global incidence of appendicitis: a systematic review of population-based studies. Ann Surg, 2017; 266(2):237-41.

Gardiner TM, Gillespie BM. Optimal time to surgery for patients requiring laparoscopic appendectomy: an integrative review. AORN J, 2016; 103(2):198-211; doi:10.1016/j.aorn.2015.12.006

Golz RA, Flum DR, Sanchez SE, Liu X, Donovan C, Drake FT. Geographic association between incidence of acute appendicitis and socioeconomic status. JAMA Surg, 2020; 155(4):330-8; doi:10.1001/ jamasurg.2019.6030

Greger HK, Myhre AK, Lydersen S, Jozefiak T. Child maltreatment and quality of life: a study of adolescents in residential care. Health Qual Life Outcomes, 2016; 14:74; doi:10.1186/s12955-016-0479-6

Haque M, Islam T, Rahman NAA, McKimm J, Abdullah A, Dhingra S. Strengthening primary health-care services to help prevent and control long-term (chronic) non-communicable diseases in low- and middle-income countries. Risk Manag Healthc Policy, 2020; 13:409-26; doi:10.2147/RMHP.S239074.

Hernandez MC, Aho JM, Habermann EB, Choudhry AJ, Morris DS, Zielinski MD. Increased anatomic severity predicts outcomes: Validation of the American Association for the Surgery of Trauma's Emergency General Surgery score in appendicitis. J Trauma Acute Care Surg. 2017;82(1):73-79. doi: 10.1097/TA.0000000000001274.

Hernandez MC, Finnesgaard E, Aho JM, Kong VY, Bruce JL, Polites SF, Laing GL, Clarke DL, Zielinski MD. Appendicitis: rural patient status is associated with increased duration of prehospital symptoms and worse outcomes in high- and kow-middle-income countries. World J Surg, 2018; 42(6):1573-80; doi:10.1007/s00268-017-4344-5

Hirsch TM. Acute appendicitis. JAAPA. 2017 Jun;30(6):46-47. doi: 10.1097/01.JAA.0000516357.34621.aa. PMID: 28538430.

Humes DJ, Simpson J. Acute appendicitis. BMJ, 2006; 333(7567):530-4; doi:10.1136/bmj.38940.664363.AE

Iftikhar MA, Dar SH, Rahman UA, et al. Comparison of Alvarado score and pediatric appendicitis score for clinical diagnosis of acute appendicitis in children - a prospective study. Ann Pediatr Surg, 2021; 17:10; doi:10.1186/s43159-021-00079-7

Islam ABMMM, Akhter N, Imam MZ, Rahman M, Rumi JUM. Socio-demographic characteristics of acute appendicitis patients attended at a tertiary care teaching Hospital in Bangladesh. Bang J Infect Dis, 2020a; 6(2):44-7; doi:10.3329/bjid.v6i2.46104

Islam F, Kathak RR, Sumon AH, Molla NH. Prevalence and associated risk factors of general and abdominal obesity in rural and urban women in Bangladesh. PLoS One. 2020b;15(5):e0233754. doi: 10.1371/ journal.pone. 0233754

Jablonski KA, Guagliardo MF. Pediatric appendicitis rupture rate: a national indicator of disparities in healthcare access. Popul Health Metr, 2005; 3(1):4.

Johnson AB. Current trends of acute appendicitis in Africa: a clinical review. Int J Healthcare Sci, 2019; 7(2):63-92.
Jones MW, Lopez RA, Deppen JG. Appendicitis. StatPearls Publishing, Treasure Island, FL, 2021. Available at: https://www.ncbi.nlm. nih.gov/books/NBK493193/ (Accessed 16 June 2021)

Committee on Improving the Health, Safety, and Well-Being of Young Adults; Board on Children, Youth, and Families; Institute of Medicine; National Research Council; Bonnie RJ, Stroud C, Breiner $\mathrm{H}$, editors. Investing in the Health and Well-Being of Young Adults. Washington (DC): National Academies Press (US); 2015 Jan 27. 6, Public Health. Available from: https://www.ncbi.nlm.nih.gov/books/NBK284781/ [Accessed 1 July 2021]

Institute of Medicine (US) Roundtable on Health Disparities. Challenges and Successes in Reducing Health Disparities: Workshop Summary. Washington (DC): National Academies Press (US); 2008. Appendix D, Community Approaches to Addressing Health Disparities. Available from: https://www.ncbi.nlm.nih.gov/books/NBK215366/ [Accessed 1 July 2021]

Keyzer C, Gevenois PA. Summary and perspectives. In: Keyzer $\mathrm{C}$, Gevenois PA (ed.). Imaging of acute appendicitis in adults and children. Springer, Heidelberg, Germany, pp 251-2, 2011.

Kim M, Kim SJ, Cho HJ. Effect of surgical timing and outcomes for appendicitis severity. Ann Surg Treat Res, 2016; 91(2):85-9; doi:10.4174/astr.2016.91.2.85

Kong VY, Aldous C, Clarke DL. Understanding the reasons for delay to definitive surgical care of patients with acute appendicitis in rural South Africa. S Afr J Surg, 2014; 52(1):2-5.

Kong VY, Bulajic B, Allorto NL, Handley J, Clarke DL. Acute appendicitis in a developing country. World J Surg, 2012; 36(9):2068-73.

Kong VY, Sartorius B, Clarke DL. Acute appendicitis in the developing world is a morbid disease. Ann R Coll Surg Engl, 2015; 97(5):390-5; doi:10.1308/003588415X14181254790608

Kong VY, Van der Linde S, Aldous C, Handley JJ, Clarke DL. Quantifying the disparity in outcome between urban and rural patients with acute appendicitis in South Africa. S Afr Med J, 2013; 103(10):742-5; doi:10.7196/samj.7109

Körner H, Söndenaa K, Söreide JA, Andersen E, Nysted A, Lende TH, Kjellevold KH. Incidence of acute nonperforated and perforated appendicitis: age-specific and sex-specific analysis. World J Surg, 1997; 21(3):313-7; doi:10.1007/s002689900235.

Kruk ME, Gage AD, Arsenault C, Jordan K, Leslie HH, RoderDeWan S, Adeyi O, Barker P, Daelmans B, Doubova SV, English M, García-Elorrio E, Guanais F, Gureje O, Hirschhorn LR, Jiang L, Kelley E, Lemango ET, Liljestrand J, Malata A, Marchant T, Matsoso MP, Meara JG, Mohanan M, Ndiaye Y, Norheim OF, Reddy KS, Rowe AK, Salomon JA, Thapa G, Twum-Danso NAY, Pate M. High-quality health systems in the sustainable development goals era: time for a revolution. Lancet Glob Health, 2018; 6(11):e1196-252.

Kucuk GO. Technical and social challenges of laparoscopic appendectomy performed in a rural setting. Ann Ital Chir, 2015; 86(4): $344-8$.

Latunji OO, Akinyemi OO. Factors influencing health-seeking behaviour among civil servants in Ibadan, Nigeria. Ann Ib Postgrad Med, 2018; 16(1):52-60.

Lee SL, Shekherdimian S, Chiu VY, Sydorak RM. Perforated appendicitis in children: equal access to care eliminates racial and socioeconomic disparities. J Pediatr Surg, 2010; 45(6):1203-7.

Lee SL, Yaghoubian A, Stark R, Shekherdimian S. Equal access to healthcare does not eliminate disparities in the management of adults with appendicitis. J Surg Res, 2011; 170(2):209-13; doi:10.1016/j. jss.2011.02.009

Lim HM, Sivasampu S, Khoo EM, Mohamad Noh K. Chasm in primary care provision in a universal health system: findings from a nationally representative survey of health facilities in Malaysia. PLoS One, 2017; 12(2):e0172229; doi:10.1371/journal.pone.0172229

Lin KB, Chan CL, Yang NP, Lai RK, Liu YH, Zhu SZ, Pan RH. Epidemiology of appendicitis and appendectomy for the low-income population in Taiwan, 2003-2011. BMC Gastroenterol, 2015b; 15:18; doi:10.1186/s12876-015-0242-1. 
Lin KB, Lai KR, Yang NP, Chan CL, Liu YH, Pan RH, Huang $\mathrm{CH}$. Epidemiology and socioeconomic features of appendicitis in Taiwan: a 12-year population-based study. World J Emerg Surg. 2015a; 10:42; doi:10.1186/s13017-015-0036-3.

Livingston EH, Fairlie RW. Little effect of insurance status or socioeconomic condition on disparities in minority appendicitis perforation rates. Arch Surg, 2012; 147(1):11-7; doi:10.1001/archsurg.2011

Madhav N, Oppenheim B, Gallivan M, Mulembakani P, Rubin E, Wolfe N. Pandemics: risks, impacts, and mitigation. In: Jamison DT, Gelband H, Horton S, Jha P, Laxminarayan R, Mock CN, Nugent R (ed.). Disease control priorities: improving health and reducing poverty. 3rd edition, The International Bank for Reconstruction and Development/The World Bank, Washington, DC, Chapter 17, 2017. Available via https://www. ncbi.nlm.nih.gov/books/NBK525302/; doi:10.1596/978-1-4648-0527-1_ ch17 (Accessed 15 June 2021).

Makoge V, Maat H, Vaandrager L, Koelen M. Health-seeking behaviour towards poverty-related disease (PRDs): a qualitative study of people living in camps and on campuses in cameroon. PLoS Negl Trop Dis, 2017; 11(1):e0005218; doi:10.1371/journal.pntd.0005218

Markar SR, Pinto D, Penna M, Karthikesalingam A, Bulathsinghala BK, Kumaran K, Hashemi M, Fernando R. A comparative international study on the management of acute appendicitis between a developed country and a middle-income country. Int J Surg, 2014; 12(4):357-60.

Narsule CK, Kahle EJ, Kim DS, Anderson AC, Luks FI. Effect of delay in presentation on rate of perforation in children with appendicitis. Am J Emerg Med, 2011; 29(8):890-3; doi:10.1016/j.ajem.2010.04.005

National Research Council, Institute of Medicine, Woolf SH, Aron L. U.S. health in international perspective: shorter lives, poorer health. National Academies Press, Washington, DC, p 4, 2013. Available via https:// www.ncbi.nlm.nih.gov/books/NBK154484/ (Accessed 16 June 2021).

Papandria D, Goldstein SD, Rhee D, Salazar JH, Arlikar J, Gorgy A, Ortega G, Zhang Y, Abdullah F. Risk of perforation increases with delay in recognition and surgery for acute appendicitis. J Surg Res, 2013; 184(2):723-9.

Pogorelić Z, Rak S, Mrklić I, Jurić I. Prospective validation of Alvarado score and pediatric appendicitis score for the diagnosis of acute appendicitis in children. Pediatr Emerg Care, 2015; 31(3):164-8; doi:10.1097/PEC.0000000000000375

Rahman SA, Kielmann T, McPake B, Normand C. Healthcareseeking behaviour among the tribal people of Bangladesh: can the current health system really meet their needs? J Health Popul Nutr, 2012; 30(3):353-65; doi:10.3329/jhpn. v30i3.12299

Rajbhandari B, Dahal GR, Pokharel RP. Comparison between Alvarado score and paediatric appendicitis score in diagnosing acute appendicitis in children. J Nepal Paed Soc, 2020; 40(3):178-84.

Sallinen V, Akl EA, You JJ, Agarwal A, Shoucair S, Vandvik PO, Agoritsas T, Heels-Ansdell D, Guyatt GH, Tikkinen KA. Meta-analysis of antibiotics versus appendectomy for non-perforated acute appendicitis. $\mathrm{Br} \mathrm{J}$ Surg, 2016; 103(6):656-67; doi:10.1002/bjs.10147

Sammalkorpi HE, Mentula P, Leppäniemi A. A new adult appendicitis score improves diagnostic accuracy of acute appendicitis--a prospective study. BMC Gastroenterol. 2014; 14:114; doi:10.1186/1471230X-14-114

Sartelli M, Viale P, Koike K, Pea F, Tumietto F, van Goor H, Guercioni $\mathrm{G}$, Nespoli A, Tranà $\mathrm{C}$, Catena $\mathrm{F}$, Ansaloni L, Leppaniemi A, Biffl W, Moore FA, Poggetti R, Pinna AD, Moore EE. WSES consensus conference: guidelines for first-line management of intra-abdominal infections. World J Emerg Surg, 2011; 6:2; doi:10.1186/1749-7922-6-2

Snyder MJ, Guthrie M, Cagle S. Acute appendicitis: efficient diagnosis and management. Am Fam Physician, 2018; 98(1):25-33.
Song DW, Park BK, Suh SW, Lee SE, Kim JW, Park JM, Kim HR, Lee MK, Choi YS, Kim BG, Park YG. Bacterial culture and antibiotic susceptibility in patients with acute appendicitis. Int J Colorectal Dis, 2018; 33(4):441-7; doi:10.1007/s00384-018-2992-z.

Stengel JW, Webb EM, Poder L, Yeh BM, Smith-Bindman R, Coakley FV. Acute appendicitis: clinical outcome in patients with an initial false-positive CT diagnosis. Radiology, 2010; 256(1):119-26; doi: 10.1148/ radiol.10091229

Sulu B, Günerhan Y, Palanci Y, İ̧̧ler B, Çağlayan K Epidemiological and demographic features of appendicitis and influences of several environmental factors. Ulus Travma Acil Cerrahi Derg, 2010; 16(1):5.

To T, Langer JC. Does access to care affect outcomes of appendicitis in children? A population-based cohort study. BMC Health Serv Res, 2010; 10:250; doi:10.1186/1472-6963-10-250

Totapally A, Martinez P, Raszynski A, Alkhoury F, Totapally BR. Do racial/ethnic and economic factors affect the rate of complicated appendicitis in children? Surg Res Pract, 2020; 2020:3268567; doi: $10.1155 / 2020 / 3268567$

van Amstel P, Gorter RR, van der Lee JH, Cense HA, Bakx R, Heij HA. Ruling out appendicitis in children: can we use clinical prediction rules? J Gastrointest Surg, 2019; 23(10):2027-48; doi:10.1007/s11605-018$3997-1$

van der Heijden J, Gray N, Stringer B, Rahman A, Akhter S, Kalon S, Dada M, Biswas A. "Working to stay healthy", health-seeking behaviour in Bangladesh's urban slums: a qualitative study. BMC Public Health, 2019; 19(1):600; doi:10.1186/s12889-019-6750-0

Vaziri M, Nafissi N, Jahangiri F, Nasiri M. Comparison of the appendicitis inflammatory response and Alvarado scoring systems in the diagnosis of acute appendicitis in children. J Med Life, 2021; 14(1):75-80; doi:10.25122/jml-2020-0031

Wagner M, Tubre DJ, Asensio JA. Evolution and current trends in the management of acute appendicitis. Surg Clin North Am, 2018; 98(5):1005-23.

Walker AR, Richardson BD, Walker BF, Woolford A. Appendicitis, fiber intake and bowel behavior in ethnic groups in South Africa. Postgrad Med J, 1973; 49(570):243-9; doi:10.1136/pgmj.49.570.243

Watkins DA, Jamison DT, Mills T, Atun T, Danforth K, Glassman A, Horton S, Jha P, Kruk ME, Norheim OF, Qi J, Soucat A, Verguet S, Wilson D, Alwan A. Universal Health Coverage and Essential Packages of Care. In: Jamison DT, Gelband H, Horton S, Jha P, Laxminarayan R, Mock CN, Nugent R (eds.). Disease control priorities: improving health and reducing poverty. 3rd edition, The International Bank for Reconstruction and Development/The World Bank, Washington, DC, Chapter 3, 2017.

Williams BM, Purcell LN, Varela C, Gallaher J, Charles A. Appendicitis mortality in a resource-limited setting: issues of access and failure to rescue. J Surg Res, 2021; 259:320-5.

Yang E, Kahn D, Cook C. Acute appendicitis in South Africa: a systematic review. S Afr J Surg, 2015; 53(3 and 4):31-8.

How to cite this article:

Iqbal T, Azad KAK, Alam MI, Haque M. An analysis of the consequences of acute appendicitis between urban and rural patients in Bangladesh. J Appl Pharm Sci, 2021; 11(08): 154-166. 